\title{
POLA EKSPRESI GEN ENHANCED GREEN FLUORESCENT PROTEIN PADA EMBRIO DAN LARVA IKAN PATIN SIAM (Pangasianodon hypophthalmus)
}

\author{
Raden Roro Sri Pudji Sinarni Dewi*), Alimuddin ${ }^{* *}$, Agus Oman Sudrajat ${ }^{* *}$, \\ Komar Sumantadinata**), dan Erma Primanita Hayuningtyas*) \\ *) Balai Penelitian Pemuliaan Ikan \\ Jl. Raya 2 Sukamandi, Subang 41256 \\ E-mail: wiewie_thea@yahoo.com \\ **) Departemen Budidaya Perairan, FPIK-Institut Pertanian Bogor \\ Jl. Rasamala, Kampus IPB Darmaga, Bogor 16680
}

(Naskah diterima: 9 April 2013; Disetujui publikasi: 12 September 2013)

\begin{abstract}
ABSTRAK
Penelitian ekspresi sementara (transient expression) dari transgen secara in vivo menggunakan gen reporter berguna untuk mendesain konstruksi gen yang akan digunakan pada penelitian transgenesis. Gen reporter yang umum digunakan dalam penelitian ekspresi sementara transgen adalah gen GFP (green fluorescent protein). Pengamatan gen EGFP (enhanced green fluorescent protein) pada embrio dan larva ikan patin siam (Pangasianodon hypophthalmus) ditujukan untuk mendapatkan informasi mengenai kemampuan promoter $\beta$-aktin ikan mas dalam mengendalikan ekspresi gen EGFP. Gen EGFP diintroduksikan ke dalam sperma ikan patin siam menggunakan metode elektroporasi. Sperma yang telah dielektroporasi digunakan untuk membuahi sel telur ikan patin siam. Pengamatan ekspresi gen EGFP dilakukan setiap enam jam dimulai dari embrio fase 2 sel sampai larva. Berdasarkan hasil penelitian, gen EGFP terekspresi pada fase embrio dan larva ikan patin siam. Puncak ekspresi gen EGFP terjadi pada fase neurula dan menurun pada fase larva. Berdasarkan penelitian ini maka ikan patin siam transgenik telah berhasil dibentuk dan promoter $\beta$-aktin ikan mas terbukti aktif dalam mengarahkan ekspresi gen asing (GFP) di dalam tubuh ikan patin siam.
\end{abstract}

KATA KUNCl: ikan patin siam, ekpresi gen, EGFP

ABSTRACT: Enhanced green fluorescent protein gene expression pattern in embryo and larvae of stripped catfish (Pangasianodon hypophthalmus). By: Raden Roro Sri Pudji Sinarni Dewi, Alimuddin, Agus Oman Sudrajat, Komar Sumantadinata, and Erma Primanita Hayuningtyas

Experiment about transient expression of the transgene in vivo using reporter genes is useful for designing gene constructs to be used in transgenesis research. Reporter genes commonly used in the study of gene expression is GFP (green fluorescent protein). Observation of EGFP gene (enhanced green fluorescent protein) expression in embryos and larvae of stripped catfish (Pangasianodon hypophthalmus) is intended to obtain information about the ability of carp $\beta$-actin promoter in controlling EGFP expression. EGFP gene was introduced into the stripped catfish sperm using electroporation method. Electroporated sperm was used to fertilize stripped catfish eggs. EGFP expression was observed every six hours starting from phase 2 cells of the embryo to larva. Based on the results, EGFP was expressed in embryonic and larval of stripped catfish. EGFP expression peak occurs at neurula stage and decreased 
in the larval phase. Based on this study, it is concluded that transgenic stripped catfish have been successfully generated and carp $\beta$-actin promoter was actively in controlling the expression of foreign gene (GFP) in stripped catfish.

\section{KEYWORDS: stripped catfish, gene expression, EGFP}

\section{PENDAHULUAN}

Ikan patin siam merupakan spesies ikan budidaya yang populer di Indonesia. Berdasarkan Rencana Strategis Kementerian Kelautan dan Perikanan 2010- 2014, ikan patin menjadi salah satu spesies budidaya yang diprioritaskan untuk ditingkatkan produksinya. Peningkatan produksi ikan patin diperlukan untuk mendukung program industrialisasi ikan patin. Strategi peningkatan produksi ikan patin siam dapat ditempuh melalui produksi induk/benih unggul. Teknologi transgenesis terbukti mampu meningkatkan karakterkarakter unggul pada ikan budidaya seperti pertumbuhan, resistensi terhadap penyakit, resistensi terhadap kondisi lingkungan ekstrim (suhu dingin), deteksi pencemaran logam berat, warna, dan sebagainya. Penelitian transfer gen telah dilakukan pada sejumlah ikan antara lain pada ikan- ikan konsumsi (nila, mas, salmon, mud loach, lele, dan sebagainya) dan ikan- ikan model (mas koki, zebra, medaka, dan sebagainya) yang umumnya digunakan dalam penelitian dasar.

Langkah awal produksi ikan transgenik dengan karakter unggul yang diinginkan adalah pembuatan konstruksi gen. Gen asing (transgen) yang diintroduksikan ke dalam sel inang diharapkan dapat terintegrasi dan terekspresi dalam tubuh inang. Penelitian produksi ikan-ikan transgenik umumnya diawali dengan pengamatan tingkat integrasi dan ekspresi transgen yang disisipkan. Gen yang umum digunakan dalam pengamatan ekspresi transgen adalah gen-gen reporter (reporter gene). Penelitian ekspresi sementara (transient expression) dari transgen secara in vivo menggunakan gen reporter berguna untuk mendesain konstruksi gen yang akan digunakan pada penelitian transgenesis (Hackett, 1993). Seleksi gen reporter untuk mengamati ekspresi sementara transgen secara in vivo memerlukan aktivitas reporter yang secara mudah dapat dideteksi, dan memiliki sensitivitas, serta spesifisitas yang tinggi. Beberapa gen reporter yang umum digunakan dalam pengamatan ekspresi sementara transgen antara lain gen lacZ (E. coli $\beta$-galactosidase),
CAT (chloramphenicol acetyl transferase), HBsAg (hepatitis B surface antigen), dan GFP (green fluor escent protein) (Guillen et al., 1996). Gen lacZ yang berasal dari bakteri E. coli merupakan salah satu gen reporter yang sangat berguna karena memiliki sensitivitas yang baik dan dapat dengan cepat terdeteksi. Pewarnaan histokimia menggunakan X-gal memudahkan deteksi enzim ini pada sel dan jaringan. Gen CAT banyak digunakan sebagai gen reporter pada penelitian- penelitian in vivo dan in vitro. HBsAg digunakan karena memiliki spesifisitas dan sensitivitas pada sistem analisis ELISA dan umumnya digunakan untuk penentuan antigen. GFP banyak digunakan untuk mengamati ekspresi sementara transgen pada ikan hidup (disarikan dari Guillen et al., 1996). Morales et al. (2001) melaporkan bahwa pada ikan zebra yang diinjeksi gen GFP di bawah kontrol promoter $\beta$-aktin ikan mas menunjukkan gen GFP terekspresi pada seluruh bagian embrio transgenik. Hal ini menunjukkan bahwa semua tipe sel mampu mengekspresikan GFP, sehingga memperluas penggunaan gen GFP sebagai gen reporter untuk studi pola ekspresi gen.

Efektivitas transfer gen pada ikan patin siam diamati dengan menggunakan konstruksi gen yang tersusun dari promoter $\beta$ - aktin ikan mas ( $\mathrm{pCcBA}$ ) dan gen EGFP (enhanced green fluor escent protein). Penelitian ini dilakukan untuk mendapatkan informasi mengenai kemampuan promoter $\beta$-aktin ikan mas dalam mengarahkan ekspresi gen EGFP dan pola ekspresi sementara gen EGFP pada fase embrio dan larva ikan patin siam. Informasi ini selanjutnya akan dijadikan acuan untuk membuat konstruksi gen sebagai langkah awal dalam proses transgenesis untuk memproduksi ikan patin siam dengan karakter unggul yang diinginkan.

\section{BAHAN DAN METODE}

\section{Koleksi Gamet}

Induk jantan dan betina yang digunakan adalah induk ikan patin siam berukuran $2-4 \mathrm{~kg}$ yang diperoleh dari Balai Penelitian Pemuliaan 
Ikan Sukamandi, Subang, Jawa Barat. Induk diseleksi berdasarkan tingkat kematangan gonad. Induk yang telah matang gonad dipindahkan ke dalam bak pemijahan. Keseragaman kematangan telur dan ovulasi diinduksi melalui penyuntikan hormon. Induk betina diberi suntikan pertama berupa HCG dengan dosis $500 \mathrm{lU} / \mathrm{kg}$ bobot. Suntikan kedua diberikan dengan selang waktu 24 jam berupa ovaprim dengan dosis $0,6 \mathrm{~mL} / \mathrm{kg}$ bobot. Stripping untuk mendapatkan sel telur dilakukan 9- 12 jam dari penyuntikan kedua. Induk jantan diinduksi melalui penyuntikan ovaprim dengan dosis $0,2-0,3 \mathrm{~mL} / \mathrm{kg}$ bobot. Stripping untuk mendapatkan sperma dilakukan 9-12 jam setelah penyuntikan.

\section{Konstruksi Plasmid}

Konstruksi gen pCcBA- EGFP (Hidayani, 2009) yang digunakan tersusun dari promoter $\beta$ - aktin ikan mas (pCcBA) dan gen enhanced green fluorescent protein (EGFP) dimodifikasi dari vektor ekspresi pEGFP-NI (Clontech). Vektor pEGFP- N1 (panjang 4,7 kb) dipotong (digesti) menggunakan enzim restriksi Kpn I dan Apa I sebelum disambungkan (diligasi) dengan sekuens promoter pCCBA (panjang 1,9 $\mathrm{kb})$. Proses digesti dilakukan dengan melarutkan $5 \mu \mathrm{L}$ pEGFP- N1; $2,5 \mu \mathrm{L}$ 10xK buffer; 5 $\mu \mathrm{L}$ BSA; $1 \mu \mathrm{L}$ enzim Kpn I; $1 \mu \mathrm{L}$ enzim Apa I; dan 35,5 $\mu \mathrm{L}$ SDW (steril distilated water). Reaksi digesti diinkubasi selama satu jam pada suhu $37^{\circ} \mathrm{C}$.

Proses ligasi (penyambungan) dilakukan dengan mencampurkan $1 \mu \mathrm{L} \mathrm{pCcBA;} \mathrm{6,5} \mu \mathrm{L} 2 \mathrm{x}$ buffer ligasi; $1 \mu \mathrm{L}$ enzim T4 DNA ligase; dan $4,5 \mu \mathrm{L}$ plasmid pEGFP- NI yang telah dipotong.
Inkubasi dilakukan selama dua jam pada suhu ruang dan dilanjutkan semalam di dalam refrigerator (suhu sekitar $4^{\circ} \mathrm{C}$ ). Peta konstruksi gen pCcBA-EGFP $(6,0 \mathrm{~kb})$ dapat dilihat pada Gambar 1.

\section{Elektroporasi Sperma}

Elektroporasi sperma dilakukan dengan menggunakan mesin Gene Pulser II (Biorad, USA). Sperma diencerkan dengan menggunakan larutan fisiologis (1:7) sebelum dicampur dengan plasmid. Elektroporasi dilakukan dengan tipe kejutan square wave dengan panjang kejutan (pulse length) 30 milidetik, kuat medan listrik (electric field strength) $125 \mathrm{~V} /$ $\mathrm{cm}$, jumlah kejutan (pulse number) tiga kali, dan interval kejutan (pulse interval) 0,1 detik (Dewi et al., 2010). Konsentrasi DNA plasmid yang digunakan adalah $10 \mu \mathrm{g} / \mathrm{mL}$ dalam TE buffer.

\section{Parameter yang Diamati}

\section{Derajat Pembuahan dan Derajat Penetasan}

Derajat pembuahan menunjukkan kemampuan sperma dalam membuahi sel telur. Adapun derajat penetasan menunjukkan keberhasilan perkembangan sel telur sampai menetas menjadi larva. Derajat pembuahan dan derajat penetasan dihitung dengan menggunakan rumus sebagai berikut:

$$
\begin{aligned}
& \text { Derajat pembuahan }=\frac{\text { Jumlah telur yang dibuahi }}{\text { Jumlah total telur }} \times 100 \% \\
& \text { Derajat penetasan }=\frac{\text { Jumlah telur yang menetas }}{\text { Jumlah telur yang dibuahi }} \times 100 \%
\end{aligned}
$$

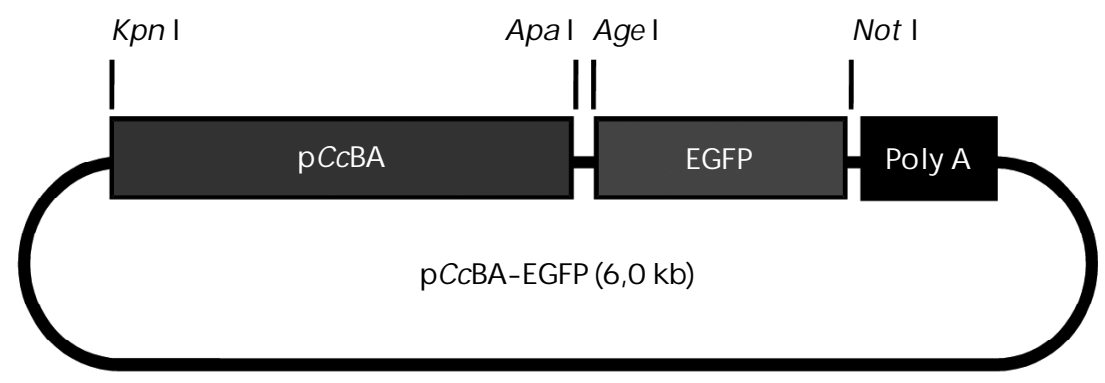

Gambar 1. Peta konstruksi gen pCcBA- EGFP $(6,0 \mathrm{~kb}), \mathrm{pCcBA}=$ promoter $\beta$ - aktin ikan mas; EGFP = enhanced green fluorescent protein; Poly $\mathrm{A}=$ poliadenilasi; Kpn I, Apa I, Age I, Not I = enzim restriksi

Figure 1. Gene construction of pCcBA-EGFP $(6.0 \mathrm{~kb})$, pCcBA $=\operatorname{carp} \beta$-actin promoter; EGFP = enhanced green fluorescent protein; Poly $\mathrm{A}=$ polyadenilation; Kpn I, Apa I, Age I, Not I = restriction enzyme 


\section{Ekspresi Gen EGFP pada Embrio dan Larva Ikan Patin Siam}

Ekstraksi RNA. RNA total diisolasi dari 50 butir embrio atau 50 ekor larva. Sampel disimpan dalam botol sampel yang telah berisi isogen sebanyak $200 \mu \mathrm{L}$. Sampel dihancurkan oleh penggerus yang sebelumnya telah disterilkan dengan DEPC 1\% Ke dalam eppendorf ditambahkan larutan isogen sampai mencapai volume akhir $800 \mu \mathrm{L}$. Chloroform p.a. sebanyak $200 \mu \mathrm{L}$ ditambahkan ke dalam eppendorf dan larutan disentrifugasi pada kecepatan 12.000 rpm selama lima menit pada suhu ruang. Supernatan yang terbentuk dipindahkan ke dalam eppendorf baru yang telah berisi 400 $\mu \mathrm{L}$ isopropanol. Larutan disentrifugasi pada kecepatan 12.000 rpm selama 15 menit pada suhu $4^{\circ} \mathrm{C}$. Pada eppendorf akan terbentuk pelet RNA, dan cairan yang terdapat pada eppendorf dibuang. Ke dalam eppendorf ditambahkan $1 \mathrm{~mL}$ alkohol 70\%(dingin) kemudian sentrifugasi dengan kecepatan $12.000 \mathrm{rpm}$ selama 15 menit. Pelet RNA dikeringkan dengan cara membuang larutan yang terdapat pada eppendorf. Sampel RNA disimpan dengan cara menambahkan $30 \mu \mathrm{L}$ DEPC $1 \%$ Konsentrasi RNA total hasil isolasi diukur menggunakan alat pengukur konsentrasi RNA/ DNA (GeneQuant). Absorbansi diukur pada panjang gelombang 260 dan $280 \mathrm{~nm}$.

Sintesis cDNA. Sintesis complementary DNA (cDNA) menggunakan kit Ready-To-Go You-Prime First Strand Beads (Amersham pharmacia biotech, USA). Konsentrasi RNA dibuat $3 \mu \mathrm{g}$ dalam $30 \mu \mathrm{L}$ DEPC. Larutan RNA diinkubasi pada suhu $65^{\circ} \mathrm{C}$ selama sepuluh menit dan kemudian disimpan di atas es. Sampel RNA dipindahkan ke dalam tube FSRMB (First strand reaction mix beads) dan ditambahkan $3 \mu \mathrm{L}$ primer 'dT3'RACE- VECT" (5'- GTA ATA CGA ATA ACT ATA GGG CAC GCG TGG TCG ACG GCC CGG GCT GGT TTT TTT TTT TTT TTT $\mathrm{T}$ - $3^{\prime}$ ) dengan konsentrasi $1 \mu \mathrm{g} / 3 \mu \mathrm{L}$. Larutan dihomogenkan dan diinkubasi pada suhu $37^{\circ} \mathrm{C}$ selama satu jam. cDNA yang terbentuk ditambahkan $30 \mu \mathrm{L}$ SDW steril dan disimpan dalam refrigerator.

Analisis Ekspresi EGFP. Ekspresi EGFP pada embrio dan larva diamati setiap enam jam dengan metode RT- PCR (rever se transcription - polymerase chain reaction). PCR dilakukan dengan menggunakan primer GFPr (5'- ACG AAC TCC AGC AGG ACC AT- 3') dan GFPf (5'- GGT CGA GCT GGA CGG CGA CG- 3'). PCR dilakukan dengan program: $94^{\circ} \mathrm{C}$ selama tiga menit; $\left(94^{\circ} \mathrm{C}\right.$ selama 30 detik; $62^{\circ} \mathrm{C}$ selama 30 detik; $72^{\circ} \mathrm{C}$ selama satu menit) sebanyak 25 siklus; $72^{\circ} \mathrm{C}$ selama tiga menit; dan $4^{\circ} \mathrm{C}$ (tak hingga). Pengecekan hasil amplifikasi PCR dilakukan dengan elektroforesis menggunakan gel agarosa $0,7 \%$ Produk amplifikasi gen EGFP berada pada ukuran sekitar 600 bp. Sebagai kontrol internal digunakan gen $\beta$ - aktin. Deteksi gen $\beta$ - aktin dilakukan dengan menggunakan metode PCR. Primer yang digunakan adalah bact- $\mathrm{F}$ (5'- TAT GAA GGT TAT GCT CTG CCC- 3') dan bact- $R$ ( $5^{\prime}$ - CAT ACC CAG GAA AGA TGG CTG$\left.3^{\prime}\right)$. PCR dilakukan dengan program: $94^{\circ} \mathrm{C}$ selama tiga menit; $\left(94^{\circ} \mathrm{C}\right.$ selama 30 detik; $58^{\circ} \mathrm{C}$ selama 30 detik; $72^{\circ} \mathrm{C}$ selama 30 detik) sebanyak 30 siklus; $72^{\circ} \mathrm{C}$ selama tiga menit; dan $4^{\circ} \mathrm{C}$ (tak hingga). Pengecekan hasil amplifikasi PCR dilakukan dengan elektroforesis menggunakan gel agarosa $1 \%$ Gen $\beta$ - aktin ikan patin siam berada pada ukuran sekitar $300 \mathrm{bp}$. Pengukuran level ekspresi gen EGFP dilakukan dengan mengukur ketebalan pita DNA hasil elektroforesis menggunakan software UNSCAN-IT gel 6.1. Hasil pengukuran level ekspresi gen EGFP dibandingkan dengan gen $\beta$ - aktin yang berfungsi sebagai kontrol loading RNA.

\section{HASIL DAN BAHASAN}

\section{Derajat Pembuahan dan Derajat Penetasan}

Pemberian kejutan listrik pada sperma pada saat dielektroporasi bertujuan untuk memberikan peluang gen eksogen masuk ke dalam sitoplasma melalui pori- pori membran sel yang terbuka. Pemberian kejutan listrik akan memengaruhi kualitas dan kuantitas sperma (Dewi et al., 2010). Berdasarkan data pada Tabel 1, sperma yang dielektroporasi memiliki kemampuan membuahi sel telur yang lebih rendah dan menghasilkan jumlah larva yang lebih sedikit dibandingkan kontrol (sperma non- elektroporasi).

Kondisi sperma ikan akan menentukan keberhasilan pembuahannya. Sperma yang baik dapat membuahi sel telur dengan baik. Terjadinya perubahan pada sperma akan memengaruhi kerja sperma. Perubahan disini adalah dalam hal pergerakan (motilitas) dan ketahanan hidupnya. Semen yang memenuhi syarat untuk proses pembuahan mengandung sperma yang hidup dan bergerak aktif ke depan (progresif). Dalam penelitian ini, derajat pembuahan dan derajat penetasan telur yang dibuahi oleh sperma yang dielektroporasi lebih 
Pola ekspresi gen enhanced green fluorescent ..... (Raden Roro Sri Pudji Sinarni Dewi)

Tabel 1. Derajat pembuahan dan penetasan telur ikan patin siam, P. hypophthalmus

Table 1. Fertilization rate and hatching rate of stripped catfish (P. hypophthalmus) eggs

\begin{tabular}{cccccc}
\hline \multirow{2}{*}{$\begin{array}{c}\text { Ulangan } \\
\text { Replication }\end{array}$} & \multicolumn{2}{c}{$\begin{array}{c}\text { Derajat pembuahan } \\
\text { Fertilization rate (\%) }\end{array}$} & & \multicolumn{2}{c}{$\begin{array}{c}\text { Derajat penetasan } \\
\text { Hatching rate (\%) }\end{array}$} \\
\cline { 2 - 3 } & $\begin{array}{c}\text { Kontrol } \\
\text { Control }\end{array}$ & $\begin{array}{c}\text { Perlakuan } \\
\text { Treatments }\end{array}$ & & $\begin{array}{c}\text { Kontrol } \\
\text { Control }\end{array}$ & $\begin{array}{c}\text { Perlakuan } \\
\text { Treatments }\end{array}$ \\
\hline 1 & 83.59 & 56.90 & & 74.80 & 100 \\
2 & 85.26 & 22.41 & & 93.42 & 14.29 \\
Rataan $\pm \mathrm{sem}$ & $84.42 \pm 0.84$ & $39.66 \pm 17.25$ & $84.11 \pm 9.31$ & $57.14 \pm 42.86$ \\
\hline
\end{tabular}

bervariasi dan lebih rendah, masing- masing $39,66 \%$ dan $57,14 \%$ dibandingkan dengan kontrol. Hal ini menunjukkan bahwa pemberian kejutan listrik pada sperma melalui elektroporasi menyebabkan penurunan kualitas sperma untuk membuahi sel telur dan menghasilkan larva.

\section{Pola Ekspresi Gen EGFP}

Kemampuan promoter $\beta$-aktin ikan mas dalam mengarahkan ekspresi gen EGFP diamati pada embrio dan larva ikan patin siam. Pengamatan pola ekspresi gen EGFP dilakukan setiap enam jam sampai embrio menetas menjadi larva. Tahapan perkembangan embrio setiap enam jam dapat dilihat pada Gambar 2. Pada penelitian ini, gen EGFP yang ditransfer pada sperma ikan patin siam melalui metode elektroporasi terbukti mampu terekspresi pada fase embrio sampai menjadi larva (Gambar 3). Gen EGFP mulai terekspresi pada jam ke- 0 (fase 2- 8 sel) dan mencapai puncaknya pada jam ke- 12 yaitu pada fase neurula. Ekspresi gen EGFP menurun pada jam ke- 30 yaitu pada fase larva (Gambar 4).

Gen asing yang diintroduksi ke ikan harus dapat ditranskripsi dan ditranslasi secara akurat dalam ikan resipien. Salah satu komponen dari konstruksi gen yang berperan dalam mengatur ekspresi gen adalah promoter. Promoter merupakan bagian dari DNA di mana RNA polimerase menempel. Promoter berfungsi untuk mengarahkan RNA polimerase sehingga transkripsi terjadi (Glick \& Pasternak, 2003) Promoter merupakan salah satu penentu ekspresi gen sehingga promoter bisa dianalogikan sebagai switch suatu gen (Hacket, 1993). Berdasarkan hasil pengamatan, ekspresi mRNA EGFP teramati pada embrio dan larva ikan patin siam. Hal ini membuktikan bahwa promoter $\beta$ - aktin ikan mas mampu mengarahkan ekspresi gen EGFP pada ikan patin siam. Hal ini serupa dengan penelitian Morales et al. (2001) yang melaporkan bahwa promoter $\beta$-aktin ikan mas terbukti mampu mengendalikan ekspresi gen GFP pada ikan zebra.

Ekspresi gen asing yang diintroduksikan ke dalam sel inang umumnya memiliki pola ekspresi yang serupa. Pada ikan patin siam, puncak ekspresi gen EGFP terjadi pada jam ke12 yaitu pada fase neurula. Puncak ekspresi DNA eksogen diduga lebih berkaitan dengan perkembangan embrio dibandingkan waktu. Pada ikan zebra (Danio rerio), puncak ekspresi DNA eksogen terjadi pada awal gastrula (Stuart et al., 1988). Pada ikan medaka terjadi pada stadia gastrula/ neurula (Chong \& Vielkiend, 1989). Pada loach (Misgurnus sp.) terjadi pada stadia akhir gastrula (MacLean et al., 1987), dan pada lele Afrika (Clarias gariepinus) terjadi pada awal gastrula (awal epiboli) (Volckaert et al., 1994). Puncak replikasi DNA ini terjadi pada Xenopus pada akhir proses pembelahan yang cepat (mid- blastula terdiri dari 4.000 sel, tujuh jam setelah fertilisasi). Pada ikan medaka, awal transkripsi gen endogen terjadi pada stadia mid- blastula (Winkler et al., 1992).

Ekspresi dari gen asing dimulai setelah fase mid- blastula dan level- nya meningkat selama embriogenesis, dan selanjutnya menurun setelah menetas (Gong \& Hew, 1993; Liu et al., 1990). Hal ini serupa dengan yang terjadi pada ikan patin siam. Pada ikan patin siam, ekspresi gen EGFP mengalami penurunan pada fase larva. Kejadian ini disebut sebagai ekspresi sementara, yang mungkin disebabkan oleh replikasi ekstrakromosomal DNA asing. Level ekspresi selanjutnya akan menurun yang diikuti dengan degradasi dari ekstrakromosomal DNA. Akibatnya, level ekspresi gen yang 


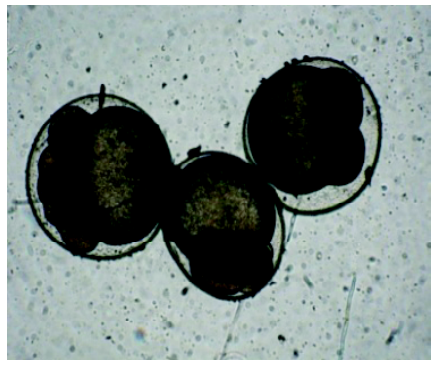

Jam ke- $0 / 0$ hour (Fase 2 - 8 sel/2-8 cells)

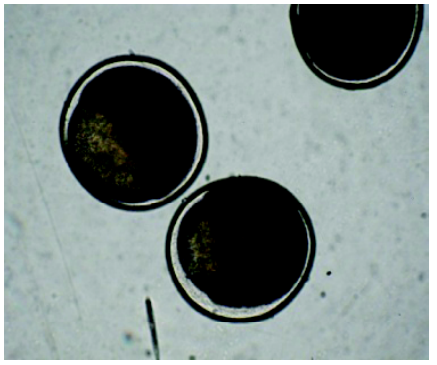

Jam ke- $6 / 6$ hours

(Fase gastrula/ gastrula)



Jam ke- 12/ 12 hours

(Fase neurula/ neurula)



Jam ke- 18/ 18 hours; (Fase organogenesis/ organogenesis)

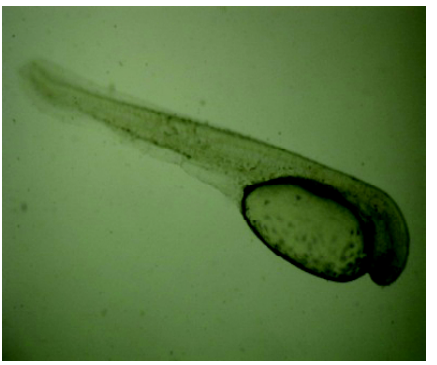

Jam ke- 30/30 hours (Fase larva/ larvae)

Gambar 2. Fase perkembangan embrio ikan patin siam P. hypophthalmus yang diamati setiap enam jam sekali.

Figure 2. Embriogenesis of stripped catfish P. hypophthalmus that was observed every six hours

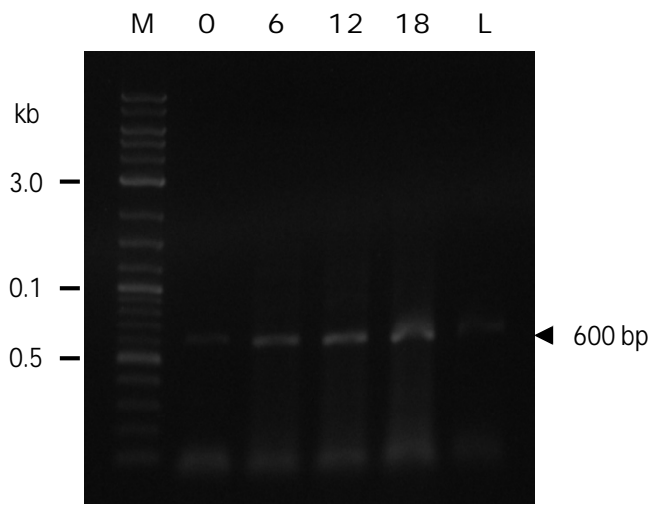

EGFP

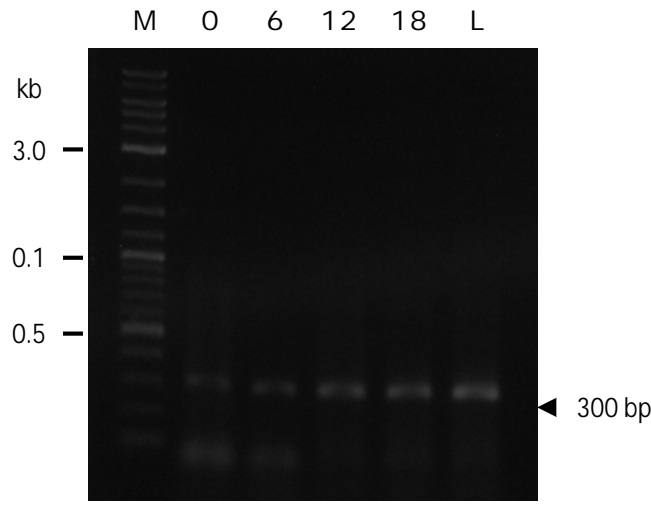

BA

Gambar 3. Pola ekspresi gen EGFP yang diamati selama perkembangan embrio sampai larva ikan patin siam $\mathrm{P}$. hypophthalmus; $\mathrm{M}=$ marker; angka 0, 6, 12, 18 menunjukkan jam pengamatan sampel; $L=$ larva; $B A=\beta$ - aktin (kontrol internal) EGFP = enhanced green fluorescent protein. Tanda kepala panah menunjukkan keberadaan DNA target

Figure 3. EGFP expression pattern that was observed in embryo and larvae of stripped catfish P. hypophthalmus; $M=$ marker; number of $0,6,12,18$ are observation time (hour); $\mathrm{L}=$ larvae; $\mathrm{BA}=\beta$-actin (internal control); $\mathrm{EGFP}=$ enhanced green fluorescent protein; head arrow showed targeted DNA 


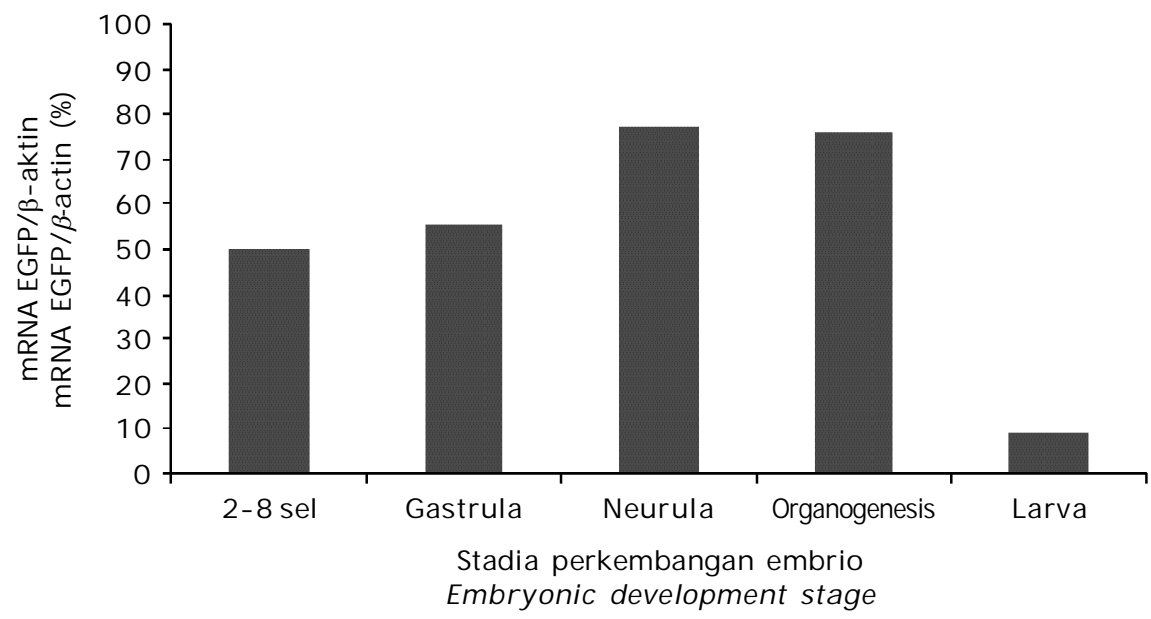

Gambar 4. Level ekspresi gen EGFP pada embrio dan larva ikan patin siam P. hypophthalmus

Figure 4. EGFP level expression in stripped catfish P. hypophthalmus embryo and larvae

terintegrasi ke kromosom resipien tidak setinggi dengan ekspresi sementara.

Keberhasilan promoter $\beta$ - aktif ikan mas dalam mengarahkan ekspresi gen EGFP pada embrio dan larva ikan patin siam menunjukkan bahwa promoter $\beta$ - aktif ikan mas aktif dalam mengawali proses transkripsi gen asing pada ikan patin siam. Hasil penelitian ini dapat digunakan sebagai dasar untuk membuat konstruksi gen lainnya yang tersusun dari promoter $\beta$-aktin ikan mas yang digabungkan dengan gen target dengan tujuan untuk mendapatkan ikan patin siam dengan karakter unggul yang diinginkan.

\section{KESIMPULAN}

Promoter $\beta$-aktin ikan mas mampu mengarahkan ekspresi gen EGFP pada ikan patin siam. Gen EGFP mulai terekspresi pada fase 2 sel, mencapai puncaknya pada fase neurula dan menurun pada fase larva. Keberhasilan ini membuka kesempatan untuk membuat konstruksi gen dengan menggunakan promoter $\beta$ - aktin ikan mas dalam rangka memproduksi ikan patin siam dengan karakteristik yang diinginkan melalui penggunaan metode transgenesis.

\section{DAFTAR ACUAN}

Chong, S.S.C. \& Vielkind, J.R. 1989. Expression and fate of CAT reporter gene microin- jected into fertilized medaka (Oryzias latipes) eggs in the form of plasmid DNA, recombinant phage particles and its DNA. Theor. Appl. Genet., 78: 369- 380.

Dewi, R.R.S.P.S., Alimuddin, Sudrajat, A.O., Sumantadinata, K., \& Sularto. 2010. Optimal electroporation condition for sperm mediated gene transfer in stripped catfish (Pangasionodon hypophthalmus). Indonesian Aquaculture J., 5(1): 1- 10.

Glick, B.R. \& Pasternak, J.J. 2003. Molecular biotechnology: principles and applications of recombinant DNA. Third ed. ASM Press. Washington D.C., p. 110- 115.

Gong, Z. \& Hew, C.L. 1993. Promoter analysis of fish antifreeze protein genes, In P.W. Hochachka and T.P. Mommsen (Eds.), "Molecular Biology Frontier". Elsevier, New York, p. 307- 324.

Guillen, I., Lleonart, R., del Barco, D.G., Martinez, R., Herrera, F., Morales, A., Herrera, M.T., Morales, R., \& de la Fuente, J. 1996. Reports genes for transgenic fish experiments. Biotecnologia Aplicada, 13: 279- 283.

Hackett, P.B. 1993. The molecular biology of transgenic fish. In Hochachka, P.W. \& Mommsen, T.P. (Eds.), Biochemistry and Molecular Biology of Fishes, Vol. 2. Elsevier Science, Amsterdam, p. 207- 240.

Hidayani, A. 2009. Isolasi dan efektivitas promoter beta actin dalam mengarahkan ekspresi gen target pada transgenesis ikan 
mas. Tesis. Program Pascasarjana, Institut Pertanian Bogor. Bogor, $35 \mathrm{hlm}$.

Liu, Z., Moav, B., Faras, A.J., Guise, K.S., Kapuscinski, A.R., \&Hackett, P.B. 1990. Development of expression vectors for transgenic fish. Mol. Cell. Biol., 10: 3,4323,440 .

MacLean, N., Penman, D., \& Zhu, Z. 1987. Introduction of novel genes into fish. Biotechnology, 5: 257- 261.

Morales, R., Herrera, M.T., Arenal, A., Cruz, A., Hernandez, O., Pimentel, R., Guillen, I. Martinez, R., \& Estrada, M.P. 2001. Tilapia chromosomal growth hormone gene expression accelerates growth in transgenic zebrafish (Danio rerio). Electronic Journal of Biotechnology, 4: 52- 58.

Stuart, G.W., McMurray, J.V., \& Westerfield, M. 1988. Replication, integration, and stable germ line transmission of foreign sequences injected into early zebrafish embryos. Development, 103: 403- 412.

Volckaert, F.A., Hellemans, B.A., Galbusera, P. Ollevier, F., Sekkali, B., \& Belayew, A. 1994. Replication, expression, and fate of foreign DNA during embryonic and larval development of the African catfish (Clarias gariepinus). Mol. Mar. Biol. Biotechnol., 3: 57-69.

Winkler, C., Hong, Y., Wittbrodt, J., \& Schartl, M. 1992. Analysis of heterologous and homologous promoters and enhancers in vitro and in vivo by gene transfer into Japanese medaka (Oryzias latipes) and Xiphophorus. Mol. Mar. Biol. Biotechnol., 1: 326- 337. 